\title{
Modified Cervicography and Visual Inspection With Acetic Acid as an Alternative Screening Method for Cervical Precancerous Lesions
}

\author{
Gatot Purwoto ${ }^{1,2}$, Hasra Depiesa Dianika ${ }^{2}$, Andre Putra ${ }^{1,2}$, Sigit Purbadi ${ }^{1,2}$, Laila Nuranna ${ }^{1,2}$ \\ ${ }^{1}$ Oncology Gynecology Division, ${ }^{2}$ Department of Obstetrics and Gynecology, Faculty of Medicine, Universitas Indonesia, Dr. Cipto Mangunkusumo \\ Hospital, Jakarta, Indonesia
}

\begin{abstract}
Background: We compared the diagnostic accuracy between visual inspection with acetic acid (VIA) and modified cervicography as an alternative screening method for cervical precancerous lesions.

Methods: A diagnostic cross-sectional study was performed at the outpatient clinic at an Indonesian national referral hospital from February until April 2015. We collected samples from patients who sequentially underwent VIA examination, modified cervicography, and colposcopy.

Results: A total of 185 patients were included in this study. Modified cervicography showed positive results in $7.6 \%$ of patients, while $7.0 \%$ of patients had a VIA positive result. This is compared to $5.4 \%$ of patients showing abnormal colposcopy results. From those results, we obtained that sensitivity and specificity of VIA were $96.0 \%$ and $90.9 \%$. Meanwhile, sensitivity and specificity of modified cervicography were $97.7 \%$ and $90.9 \%$, respectively, compared to colposcopy as a gold standard.

Conclusions: Modified cervicography and VIA are reliable tools for cervical cancer screening, with comparable sensitivity and specificity. Modified cervicography can be used as a supplementary tool to improve the documentation of VIA and as an alternative to VIA alone. (J Cancer Prev 2017;22:254-259)
\end{abstract}

Key Words: Colposcopy, Modified cervicography, Sensitivity and specificity, Visual inspection with acetic acid

\section{INTRODUCTION}

Cervical cancer holds the rank as the most common cancer, both in general and in females. Human papillomavirus (HPV) is detected in $99.7 \%$ of cervical cancer cases, making HPV infection a very important part in the development of cervical cancer. ${ }^{1-3}$

In order to improve survival rate and decrease the morbidity of cervical cancer, current efforts are aimed to detect the disease earlier. The main reason for the high incidence in developing countries is the lack of effective screening programs directed at the detection and early management of cervical cancer, especially in the pre-cancerous lesion phase. Cytology- based screening is difficult to carry out in low resource settings because it is expensive, requires complicated training by laboratory technicians, and includes competition between health services. In addition, mass screening with Pap smear cannot be accomplished due to the shortage of pathologists and cytology technicians. Therefore, there is a need for an alternative assessment method for screening. This study will report on two alternative screening methods, namely, modified cervicography and visual inspection with acetic acid (VIA). This will be done through assessing diagnostic accuracy; i.e., sensitivity, specificity, positive predictive value (PPV), and negative predictive value (NPV). These methods will then be compared to colposcopy as the gold standard for the detection of cervical cancer lesions. ${ }^{46}$

Currently, the development of the digital era can be seen in all

Received September 18, 2017, Revised December 7, 2017, Accepted December 7, 2017

Correspondence to: Gatot Purwoto

Oncology Gynecology Division, Department of Obstetrics and Gynecology, Faculty of Medicine, Universitas Indonesia, Dr. Cipto Mangunkusumo Hospital, Jalan Diponegoro No. 71, Jakarta Pusat, Jakarta 10430, Indonesia

Tel: +62-2131908617, Fax: +62-213101737, E-mail: gatotpurwoto@gmail.com, ORCID: Gatot Purwoto, http://orcid.org/0000-0001-5019-2707

Copyright (C) 2017 Korean Society of Cancer Prevention

(c) This is an Open Access article distributed under the terms of the Creative Commons Attribution Non-Commercial License (http://creativecommons.org/licenses/by-nc/4.0) which permits unrestricted non-commercial use, distribution, and reproduction in any medium, provided the original work is properly cited. 
aspects of life. The Female Cancer Program in Indonesia through Gatot Purwoto, MD, PhD has developed a modified device inspired by this digital development. The device is called modified cervicography, and hopes to become the new breakthrough in the early detection of cervical cancer. Modified cervicography has many advantages, such as the visual capability that is comparable to colposcopy in visualizing the portio, ostium, squamocolumnar junction (SCJ), abnormal cervical appearance, and blood vessels. On the other hand, this device requires optimal resources in the application, but it is very easy to document and can become a means of consultation. The cost of examination is low, as this device only need a digital camera and can be used repeatedly over the course of many years. Due to these reasons, we need to carry out this research in order to assess if modified cervicography can be used in the general population for the screening of cervical (pre)cancerous lesions.

\section{MATERIALS AND METHODS}

Data collection took place between February 2015 and April 2015 in the Gynecologic Oncology outpatient clinic at Dr. Cipto Mangunkusumo Hospital, a national referral center in Jakarta, Indonesia. Sexually active women aged 20 to 55 years old were included in our study, whilst the exclusion criteria included women who did not agree to be involved in the study, those in whom the portio was not adequately visible during examination, or those who were pregnant.

Using diagnostic study sampling formulas to determine the size of each group, we recruited 185 samples for VIA and modified cervicography. Sample recruitment was conducted through consecutive sampling. All patients who are at risk for cervical cancer and were willing to undergo modified cervicography and VIA were recruited until the minimal sample was achieved.

Patients who fulfilled the inclusion criteria were given information regarding the study and if they agreed to be involved in this study, the patients were asked to sign a consent form. Subsequently, the patient was interviewed to obtain data to fill the study form and have basic physical examination done. This was done by several teams, who were informed on the study design and required procedures, in order to ensure standardization. The main researcher performed the VIA, modified cervicography, and colposcopy examination. The results obtained were assessed by the main researcher and two observers in order to minimize any possible bias. The results were documented and analyzed accordingly. The results of cervicography were transferred from the camera to an available personal computer or laptop for processing, and then sent to two competent gynecologic oncology consultants.

The data was recorded in table form, which had been designed previously and analyzed using IBM SPSS Stastics ver. 20 (IBM Co., Armonk, NY, USA). Data was inserted into a $2 \times 2$ table, and the diagnostic value was presented in the form of sensitivity, specificity, and predictive values of all the examinations.

This study had been approval by ethical committee from Faculty of Medicine, Universitas Indonesia with approval number 106/UN2.F1/ETIK/II/2015 and for informed consent.

\section{RESULTS}

Table 1 shows the characteristics of our patients. Our data follow a normal distribution and are presented in median (range;

Table 1. Characteristics of study samples $(\mathrm{n}=185)$

\begin{tabular}{|c|c|}
\hline Variable & Value \\
\hline \multicolumn{2}{|l|}{ Age (yr) } \\
\hline $20-30$ & $13(7.0)$ \\
\hline $31-50$ & $143(77.3)$ \\
\hline$>50$ & $29(15.7)$ \\
\hline \multicolumn{2}{|l|}{ Age at marriage (yr) } \\
\hline$<20$ & $34(18.4)$ \\
\hline$\geq 20$ & $151(81.6)$ \\
\hline \multicolumn{2}{|l|}{ Marriage } \\
\hline 1 time & $177(95.7)$ \\
\hline$>1$ times & $8(4.3)$ \\
\hline Length of marriage (yr) & $18(1-35)$ \\
\hline \multicolumn{2}{|l|}{ Contraceptive method } \\
\hline Not using any contraceptives & $116(62.7)$ \\
\hline Oral contraceptives (pills) & $8(4.3)$ \\
\hline Monthly injectable contraceptives & $5(2.7)$ \\
\hline Quarterly injectable contraceptives & $16(8.6)$ \\
\hline Intrauterine device & $30(16.2)$ \\
\hline Female sterilization & $6(3.2)$ \\
\hline Implants & $1(0.5)$ \\
\hline Condoms & $3(1.6)$ \\
\hline \multicolumn{2}{|l|}{ Vaginal discharge } \\
\hline Present & $86(46.5)$ \\
\hline Absent & $99(53.5)$ \\
\hline \multicolumn{2}{|l|}{ Cervicitis } \\
\hline Present & $22(11.9)$ \\
\hline Absent & $163(88.1)$ \\
\hline \multicolumn{2}{|l|}{ Post-coital bleeding } \\
\hline Present & $15(8.1)$ \\
\hline Absent & $170(91.9)$ \\
\hline \multicolumn{2}{|l|}{ Smoking } \\
\hline No & $181(97.8)$ \\
\hline Yes & $4(2.2)$ \\
\hline
\end{tabular}

Values are presented as number (\%) or median (range). 
minimum to maximum); categorical data are presented as the sum and percentage. The total number of samples is 185 samples. $77.3 \%$ of patients were between 31 and 50 years old. In addition, $81.6 \%$ of patients were older than 20 at marriage.

Table 2 displays that the SCJ was visualized in $86.5 \%$ of all the samples examined. For those patients in whom the SCJ was not visible, VIA examination, modified cervicography, and colposcopy were still performed because the presence of acetic white lesion can be expected in the transformation zone.

Table 3 shows that for all three examinations, $7.0 \%$ of patients had a VIA positive results, positive results for modified cervicography were found in $7.6 \%$ of patients, and results for abnormal colposcopy was $5.4 \%$.

Table 4 and 5 show the $2 \times 2$ tables of VIA examination and modified cervicography in comparison to colposcopy. Based on the $2 \times 2$ tables, we can obtain the diagnostic values as calculated using their respective formulas, and the diagnostic accuracy in the form of sensitivity, specificity, PPV, NPV, positive likelihood ratio (PLR), and negative likelihood ratio (NLR), as presented in Table 6.

This study showed that the sensitivity of VIA was $96.0 \%$, while

Table 2. Results of SCJ visualization

\begin{tabular}{ccc}
\hline Variable & Not visible & Visible \\
\hline SCJ & $25(13.5)$ & $160(86.5)$ \\
\hline
\end{tabular}

Values are presented as number (\%). SCJ, squamocolumnar junction.

Table 3. Results of VIA examination, cervicography, and colposcopy

\begin{tabular}{lcc}
\hline \multicolumn{1}{c}{ Variable } & Negative & Positive \\
\hline VIA & $172(93.0)$ & $13(7.0)$ \\
Modified cervicography & $171(92.4)$ & $14(7.6)$ \\
Colposcopy & $175(94.6)$ & $10(5.4)$ \\
\hline
\end{tabular}

Values are presented as number (\%). VIA, visual inspection with acetic acid.

Table 4. Two $\times$ two table of VIA examination

\begin{tabular}{lrcc}
\hline & \multicolumn{3}{c}{ Colposcopy } \\
\cline { 2 - 4 } & Positive & Negative & Total \\
\hline VIA & & & \\
Positive & 167 & 1 & 168 \\
Negative & 7 & 10 & 17 \\
Total & 174 & 11 & \\
\hline
\end{tabular}

Values are presented as number only. VIA, visual inspection with acetic acid. the sensitivity of modified cervicography was $97.7 \%$. The specificity of both VIA and modified cervicography was $90.9 \%$. The PPV for both VIA and modified cervicography was $99.4 \%$, while the NPV for VIA and modified cervicography were $58.8 \%$ and $71.4 \%$, respectively.

Sensitivity is the ability of a diagnostic tool to give a positive result in patients who are positive for the disease. Meanwhile, specificity is the ability of a diagnostic tool to give a negative result in patients who are truly negative for the disease. However, clinical interpretation is highly affected by the PPV and NPV. From the PPV, clinicians can consider that the positive result is really a positive result. Likewise, from the NPV, clinicians can consider that the negative result is really a negative result. The values of PPV and NPV are highly influenced by the disease prevalence. PLR is the ratio of the number of patients who had a positive result in the group who were positive for the condition, compared to the number of samples who had a positive result in the group who were negative for the condition. Conversely, NLR is the ratio of samples who had a negative result in the group who were positive for the disease, compared to those in the group who were negative for the disease.

Table 5. Two $\times$ two table of modified cervicography

\begin{tabular}{lrcr}
\hline & \multicolumn{3}{c}{ Colposcopy } \\
\cline { 2 - 4 } & Positive & Negative & Total \\
\hline Modified cervicography & & & \\
$\quad$ Positive & 170 & 1 & 171 \\
$\quad$ Negative & 4 & 10 & 14 \\
Total & 174 & 11 & \\
\hline
\end{tabular}

Values are presented as number only.

Table 6. Diagnostic values of VIA examination and modified cervicography

\begin{tabular}{lcc}
\hline Diagnostic value & VIA & Modified cervicography \\
\hline Sensitivity & $96.0 \%$ & $97.7 \%$ \\
Specificity & $90.9 \%$ & $90.9 \%$ \\
PPV & $99.4 \%$ & $99.4 \%$ \\
NPV & $58.8 \%$ & $71.4 \%$ \\
PLR & 10.56 & 10.75 \\
NLR & 0.04 & 0.03 \\
Accuracy & 0.96 & 0.97 \\
\hline
\end{tabular}

VIA, visual inspection with acetic acid; PPV, positive predictive value; NPV, negative predictive value; PLR, positive likelihood ratio; NLR, negative likelihood ratio. 


\section{DISCUSSION}

Risk factors for the occurrence of cervical cancer include age of first sexual intercourse, smoking, and the use hormonal contraceptives, amongst others. In our study, only $18.4 \%$ of patients were married at under 20 years of age. In addintion, only $2.2 \%$ of the patients in our sample smoked. Studies have shown that the risk for cervical cancer increases with the number of cigarettes consumed, but is not related to the duration of smoking in years. ${ }^{3.7}$ Hormonal contraception use has also been found to increase the risk for cervical cancer, and use of hormonal contraceptives for 10 years increases the risk up to two-fold. ${ }^{8}$ Our study found that oral contraceptives were used by $4.3 \%$ of our sample, monthly and quarterly injectable contraceptives by $2.7 \%$ and $8.6 \%$, respectively, and implants by $0.5 \%$ of the total sample. Other risk factors for the occurrence of cervical cancer in our sample include a total $46.5 \%$ of patients complaining of vaginal discharge and $8.1 \%$ with post-coital bleeding. Furthermore, $11.9 \%$ patients presented with cervicitis upon exammination.

We were able to visualize the SCJ in $86.5 \%$ of samples. The acetic white lesion is expected to be visible within the transformation zone. In the remaining $13.5 \%$ of our samples, the SCJ could not be seen. In our study, what is defined as the SCJ not being visible is the image/exposed during examination, and not anatomically. SCJ that is not visible could be mature metaplasia, where the new SCJ will grow towards the columnar cells, which is usually marked by the lines taken through the nabothian cysts.

VIA examination relies highly on the condition of the SCJ in the cervix. In women of reproductive age and in pregnant women, the SCJ is located in the ectocervix, thus allowing it to be visualized through direct examination. However, in post-menopausal women, the SCJ is often located in the endocervical canal, thus hindering the visualization through direct examination. ${ }^{9}$ A prospective and descriptive study by Dhaubhadel et al. ${ }^{10}$ on women aged 20 to 50 years old found negative VIA and Pap smear results in all of the samples belonging to the age group of 46 to 50 years old. Nevertheless, the study did not mention whether the SCJ could be visualized or not, making it possible for the results to be a false negative. In the study carried out by Nuranna ${ }^{11}$ on women aged 20 to 70 years of age, the percentage of SCJ that was visible in post-menopausal women was $64.28 \%$, while in as much as $11.66 \%$, the SCJ was not visible.

Cervicography is a diagnostic tool that is very sensitive to assess the transformation zone and the endocervical canal, thus it is more sensitive in young women, where most of the transformation zone is visible in the ectocervix. In women who are older, the transformation zone has moved into the cervical canal, making it difficult to assess the SCJ using cervicography. Cervicography is not only useful in assessing acetic white lesions, it is also appropriate to assess other cervical findings, such as the presence of nabothian cysts and cervicitis. In conditions where the SCJ cannot be visualized, it is mostly in the post-menopausal period. In our study, the proportion of samples who were aged more than 50 years old was as much as $15.7 \%$.

Based on several studies, a study performed in Zimbabwe in 1999 indicated that the sensitivity and specificity of VIA was $77 \%$ and 64\%, respectively (University of Zimbabwe, 1999). ${ }^{12}$ Another study by Denny et al. ${ }^{13}$ demonstrated that the sensitivity of VIA was $67 \%$, with the specificity being $88 \%$. Futhermore, Sauvaget et al. ${ }^{14}$ found that VIA sensitivity was $96 \%$, with a specificity of $65 \%$. All of the studies were carried out by trained nurses and midwives. Our study found that the sensitivity of VIA was $96.0 \%$, with a specificity of $90.9 \%$. These values were higher compared to previous studies, which could be due to the fact that our study was carried out by trained medical personnel.

Several studies express that VIA is superior as a screening method because it utilizes direct vision aided by a light source and does not involve magnification. In other words, 'what you see is the reality'.

Tawa et $\mathrm{al}^{15}$ demonstrated that, when comparing cervicography to cytologic examination, the sensitivity of cervicography is higher, with a lower specificity. According to the International Federation of Obstetrics and Gynecology (2006), ${ }^{16}$ the sensitivity and specificity of cervicography is $81.0 \%$ and $75.4 \%$, respectively. However, there has been no study on the diagnostic tool that is modified cervicography. In this study, we observed the sensitivity and specificity of modified cervicography to be $97.7 \%$ and $90.9 \%$, respectively. This value is considerably higher than the sensitivity and specificity of conventional cervicography.

Modified cervicography utilizes a Sony Type W220 camera (Sony Electronic Inc., San Diego, CA, USA) with 18 megapixels and magnification ability that can be adjusted to the distance between the camera and the cervical portio, allowing the image taken to be more focused on the portio. The camera also includes a macro application that functions to make the object clearer or more focused for images taken from a very close distance. The camera used is supported by a ring light that is comprised of 3 wide spectrum lamps (9 Volt) and assembled in a serial arrangement in order to decrease the thermal effect. This ring light functions to provide maximal lighting and diminish any shadows. This 
modified cervicography can be documented in the form of soft copy or hard copy with good results, allowing the results to be evaluated by the clinician or consulted to a gynecologic oncologist ('what you see is what you get'). However, despite the many benefits of the modified cervicography (such as a high resolution and the ability to easily detect and save findings for documentation and consultation), possible drawbacks include that the device is unstable in inexperienced hands.

Colposcopy is still the gold standard for cervical cancer screening in Indonesia. According to Cronjé $^{17}$ in 2004, the sensitivity and specificity of colposcopy is more than $90 \%$. In this study, we found the incidence of abnormal colposcopy to be $5.4 \%$. The colposcopy device we used in this study is the Germany-made Kaps SOM Colposcope series 52/42, aged more than 10 years. The colposcopy device utilized a $12 \mathrm{~V} / 100 \mathrm{~W}$ coaxial halogen light (direct). It is also equipped with a standing light and a rotary green filter. The standard distance used was 25 to $30 \mathrm{~cm}$ between the device and the portio. Magnification is divided into 5 steps, and 1 to 6 times zoom capability. Colposcopy is a standard diagnostic examination for precancerous lesions of the cervix. The device is considerably stable due to the use of the tripod, with a relatively clear visual field. The aim of colposcopy examination is not only to visualize the acetic white changes but also to assess the vascular pattern. Documentation is obtained before and after exposure to acetic acid. In this study, we encountered some troubles with the connection between the camera and the monitor screen, and the result that was obtained was not in digital form but in printed form with unsatisfactory quality where a clearer image should have been able to be obtained.

We can see from our results that the sensitivity and specificity of VIA and modified cervicography was quite good. Several studies have described that the right resources and the high resolution of the modified cervicography can increase the sensitivity and specificity.

Cervicography also demonstrated a considerably high false positive number, this being the reason stated by several researchers for the method's incapacity. ${ }^{18}$

This study is a diagnostic study, where the result of the examination was assessed by two gynecologic oncologists, Gatot Purwoto, MD, PhD and Laila Nuranna, MD, PhD. We assessed the inter-observer consistency with Kappa to maintain the accuracy of our results. From the consistency evaluation, we obtained the inter-rater agreement between the two assessors. Cervicography examination shows a really good consistency (kappa $=0.957$ ). Likewise, colposcopy also shows a really good value of consistency (kappa $=1)$.

\section{CONFLICTS OF INTEREST}

No potential conflicts of interest were disclosed.

\section{REFERENCES}

1. Sawaya FG, Smith-McCune KK. The global library of women's medicine. http://www.glowm.com/?p=glowm.cml/section_view\&articleid $=19 \& S E S S I D=$ fbevf786a70ljavaf6skr0i5i1 \#25861. Accessed May, 2010.

2. Miller A, Sankaranarayanan R, Bosch X. Cervical cancer screening in developing countries epidemiological status of cervical cancer. Geneva, Collaboratively by Programme on Cancer Control, Department of Reproductive Health and Research WHO, 2002.

3. Andrijono. Kanker serviks. 2nd ed. Jakarta, Divisi Onkologi Departemen Obstetri dan Ginekologi Fakultas Kedokteran Universitas Indonesia, 2009.

4. Cronjé HS, Cooreman BF, Beyer E, Bam RH, Middlecote BD, Divall PD. Screening for cervical neoplasia in a developing country utilizing cytology, cervicography and the acetic acid test. Int J Gynaecol Obstet 2001;72:151-7.

5. De Vuyst H, Claeys P, Njiru S, Muchiri L, Steyaert S, De Sutter P, et al. Comparison of pap smear, visual inspection with acetic acid, human papillomavirus DNA-PCR testing and cervicography. Int J Gynaecol Obstet 2005;89:120-6.

6. Ocviyanti D. Tes Pap, Tes HPV, dan servikografi sebagai pemeriksaan triase untuk tes IVA Positif: Upaya tindak lanjut deteksi dini kanker serviks pada fasilitas kesehatan dengan sumber daya terbatas beserta analisis sederhana efektivitas biayanya. Upaya tindak lanjut deteksi dini kanker serviks 2007;31:201-11.

7. Baziad A, Moeloek FA, Wiknjosastro H, Junizaf, Nuranna L. Ilmu kandungan. 2nd ed. Jakarta, Yayasan Bina Pustaka Sarwono Prawohardjo, 1999.

8. Moreno V, Bosch FX, Muñoz N, Meijer CJ, Shah KV, Walboomers $\mathrm{JM}$, et al.; International Agency for Research on Cancer Muticentric Cervical Cancer Study Group. Effect of oral contraceptives on risk of cervical cancer in women with human papillomavirus infection: the IARC multicentric case-control study. Lancet 2002;359:1085-92.

9. Belinson JL, Pretorius RG, Zhang WH, Wu LY, Qiao YL, Elson P. Cervical cancer screening by simple visual inspection after acetic acid. Obstet Gynecol 2001;98:441-4.

10. Dhaubhadel P, Vaidya A, Choudhary P. Early detection of precursors of cervical cancer with cervical cytology and visual inspection of cervix with acetic acid. JNMA J Nepal Med Assoc 2008;47:71-6.

11. Nuranna L. Skrining kanker serviks dengan metode skrining alternatif: IVA. Cermin Dunia Kedokteran. Jakarta, Subbagian Onkologi, Bagian Obstetri dan Ginekologi Fakultas Kedokteran Universitas Indonesia, 2001.

12. Visual inspection with acetic acid for cervical-cancer screening:test qualities in a primary-care setting. University of Zimbabwe/JHPIEGO Cervical Cancer Project. Lancet 1999:353: 869-73.

13. Denny L, Quinn M, Sankaranarayanan R. Chapter 8: Screening for cervical cancer in developing countries. Vaccine 2006:24:S71-7. 
14. Sauvaget C, Fayette J, Muwonge R, Wesley R, Sankaranarayanan R. Accuracy of visual inspection with acetic acid for cervical cancer screening. Int J Gyneacol Obstet 2011;113:14-24.

15. Tawa K, Forsythe A, Cove J, Saltz A, Peters H, Watring N. A comparison of the Papanicolaou smear and the cervigram: sensitivity, specificity, and cost analysis. Obstet Gynecol 1988:71:229-35.

16. Bomfim-Hyppólito S, Franco ES, Franco RG, de Albuquerque CM
Nunes GC. Cervicography as an adjunctive test to visual inspection with acetic acid in cervical cancer detection screening. Int J Gynaecol Obstet 2006;92:58-63.

17. Cronjé HS. Screening for cervical cancer in developing countries. Int J Gynaecol Obstet 2004;84:101-8.

18. Spitzer M. Cervical screening adjuncts: recent advances. Am J Obstet Gynecol 1998;179:544-56. 